Araştırma Makalesi

\title{
İletişim Fakültesi Öğrencilerinin Medya Okuryazarlık Algıları ve Medya Okuryazarlığı Eğitimine Yaklaşımları
}

\author{
Aysun Köktener (Dr. Öğr. Üyesi) \\ İstanbul Aydın Üniversitesi İletişim Fakültesi \\ aysunkoktener@yahoo.com \\ Orcid: 0000-0001-6846-9196
}

Başvuru Tarihi: 18.08.2018

Yayına Kabul Tarihi: 05.12.2018

Yayınlanma Tarihi: 21.01.2019

\section{Öz}

Hızla gelişen ve dönüşen iletişim teknolojileriyle birlikte kitle iletişim araçlarının kullanımı, zaman ve mekan sınırı olmaksızın hayatın vazgeçilmez unsurlarından biri haline geldi. Kitle iletişim araçları ve yeni medyanın gelişimiyle birlikte toplumsal etkileșimin çoğalması, iletişimin ticarileşerek ulusal ve uluslararası sermayenin kontrolüne girmesi, kamu denetiminin yetersiz oluşu medya iletilerine eleştirel bir bakış açısıyla yaklaşılmasını zorunlu hale getirmektedir. Bu bağlamda, bireyleri bilinçlendiren, bilgiyi yorumlayabilen ve sorgulayabilen bir bakış açısına kavuşturabilmek açısından, medya okuryazarlığı eğitimi büyük önem taşımaktadır. $\mathrm{Bu}$ çalışmanın amacı İletişim Fakültesi öğrencilerinin medya okuryazarlığı ve Medya Okuryazarlığı dersini nasıl algıladığı ile ilköğretim eğitiminde alınan Medya Okuryazarlığı dersinin, medyaya yönelik bilinçlenme yaratıp yaratmadığının saptanmasıdır. Bu amaç doğrultusunda İstanbul Aydın Üniversitesi İletişim Fakültesi öğrencilerinden Medya Okuryazarlığı dersi eğitimi almış 2., 3. ve 4. sınıfta öğrenim gören 265 kişilik bir gurupla anket çalışması yapılmıştır. Ayrıca yarı yapılandırılmış görüşme tekniği kullanılarak, ilköğretimde verilen Medya Okuryazarlığı dersinin etkinliği saptanmaya çalışılmıştır. Yapılan çalışmada elde edilen veriler, SPSS 24.0 (Statistical Package for Social Science) paket programında işlenerek analiz edilmiş ve tablolar halinde sunulmuştur. Araştırma sonucunda Medya Okuryazarlığı dersinin katılımcıların medyaya yaklaşımlarında ve medyayı kullanım alışkanlıklarında farklılık yarattığı saptanmış, öğrencilerin medya içeriklerine karşı çok yönlü ve eleştirel bir bakış açısı kazandığı belirlenmiştir.

Anahtar Kelimeler: Medya, Medya Okuryazarlığı, Medya Okuryazarlığı Eğitimi. 
Research Article

\title{
Communication Faculty Students' Media Literacy Perceptions and Approaches to Media Literacy Education
}

\author{
Aysun Köktener (Asst. Prof. Dr.) \\ İstanbul Aydın University Faculty of Communication \\ aysunkoktener@yahoo.com \\ Orcid: 0000-0001-6846-9196
}

Date Received: 18.08.2018

Date Accepted: 05.12.2018

Date Published: 21.01.2019

\begin{abstract}
Consistent with the rapidly developing communication technology, use of the mass media has become a significant force in our life, defying time and space restrictions. With this development in the mass media and new media comes the increase in social influence, which, along with commercialization of communication controlled by national and international capital, and lack of public supervision necessitates a critical approach to media communication. In this context, the media literacy has become very important to raise individuals' awareness, and ability to interpret and question the knowledge. The purpose of this study is to determine how the students in the Faculty of Communication perceive the media literacy and its education. In addition to this, the study aims at understanding how media literacy education in elementary school curriculum raises awareness about the functioning of the media. With this purpose in mind, this study surveyed 265, 2nd 3rd and 4th year The Faculty of Communication of Istanbul Aydin University's students who took the Media Literacy class. In addition, by using the technique of semi-structured interview this study also aims at exploring the impact of the media literacy class in the elementary education. The data resulting from this study was analyzed in the SPSS 24,0 program and the results of participants' views of the subject are presented in tables. The result of the research has determined that the participants of the Media Literacy Class registered a noticeable difference in their approach to media and in their overall habits towards the use of it. In addition, it is concluded that students gained critical and well-rounded appreciation for the content of media.
\end{abstract}

Keywords: Media, Media literacy, Media literacy Education. 


\section{Giriş}

Bilgi ve iletişim teknolojilerindeki hızlı gelişmeler, giderek bilginin küreselleşmesine neden olurken, insanların iletişim biçimleri ve iletişim ortamları farklılaşmakta, kitle iletişim araçlarının kapsamı genişlemektedir. Bu bağlamda medya, çeşitli mesajları, farklı sosyo-demografik özelliklere sahip kitleye, kendi yayın politikasına uygun biçimde formatlayarak, tek yönlü yayan, kitle iletişim aracı olarak tanımlanmaktadır (Mora, 2008). Bu da medyanın kişileri ve toplumu dönüştürme, değiștirme, yönlendirme yetisine sahip olduğunu göstermektedir. Bu yetiye karşı bireylerin kitle iletişim araçlarıyla sunulan mesajlara karşı duyarlılık geliștirmeleri gerekmektedir. Hobbs'un $(2004,124)$ ifadesi ile bireyler kurgulanan, ekonomik, sosyal, siyasal, tarihsel ve estetik bağlamlar içerisinde üretilmekte olan medya mesajlarını okuyabilme becerisine sahip olmalıdır. Schopenhauer $(2016,9)$ "okumakla harfler sözcüklere, sözcükler cümlelere, cümleler de daha büyük anlam bütünlüklerine derlenip toplanır" diyerek okumanın bir bakıma bir araya getirme ve toplama yetisi olduğunu belirtir.

Medya okuryazarlığı da medyanın belirtilen özelliklerine karşı bireylerin mesajla karşı karşıya kaldıklarında doğruluğunu araştırdığı, analiz ettiği, eleştirel yaklaştığı ve bilgiyi kendilerinin yapılandırdığı bir araya getirme becerisi olmaktadır. Çünkü kitle iletişim araçlarının gelişimine paralel olarak iletişim kanallarının çeşitlenmesi, doğru bilgiye nasıl ulaşılacağına dair sorunları da beraberinde getirmiştir (Solmaz ve Yılmaz, 2012, 60). Dolayısıyla medya okuryazarlığı özellikle iletişim araçlarının ve görsel medyanın çeşitlenmesiyle birlikte önem kazanan bir kavram olmuş ve bu doğrultuda saatlerini televizyon ve internet karşısında geçiren genç neslin medya okuryazarlığı eğitimi alması kaçınılmaz hale gelmiştir (Gedik, 2015, 781).

Medyanın sağladığı olanakların yanı sıra medyanın artan çeşitliliği ve bu çeşitliliğin her yaştaki bireyleri etkileme gücünün, medya okuryazarlığı kavramını ortaya çıkardığı konusunda birçok araştırmacı hemfikirdir (Kurt ve Kürüm, 2010, 20-34; Aybek ve Demir, 2014, 50; Som ve Kurt, 2012). Günümüzde önemi daha da ortaya çıkan medya okuryazarlığı, yazılı ve yazılı olmayan, büyük çeşitlilik gösteren biçimlerdeki (televizyon, video, sinema, reklamlar, internet vs.) mesajlara ulaşma, bunları çözümleme, değerlendirme ve iletme yeteneği kazanabilmek olarak tanımlanmaktadır (Gomez ve Gomez, 2007; Manzo, 2007). Bir başka anlatımla, medya okuryazarlığı, bireyin medya araçlarından yararlanması ve onları kullanmasını bilerek, gazete, dergi, radyo, televizyon gibi geleneksel medyadan, internet, cep telefonu, oyun konsolları gibi yeni medyadan gelen mesajları alması, algılaması, özümseyerek bilinç süzgecinden geçirmesi, eleştirel bakış açısıyla yorumlayıp değerlendirmesi ve bir başkasına iletmesidir (Aslan ve Basel, 2017, 1355).

Dolayısıyla medya okuryazarı medya içeriklerini bilinçli bir şekilde değerlendirebilen ve medya içeriklerine eleștirel bir bakış açısıyla yaklaşan kişidir. "Medya okuryazarı olmak demek medya hakkındaki gerçekleri ve istatistikleri ezberlemek değil; seyrettiği, okuduğu ve duydukları hakkında doğru sorular sormayı öğrenmek demektir" (Jolls ve Thoman, 2008, 33). Medya okuryazarı olan bir birey medya üzerinden bilgiye ulaşabilen, bu bilgileri analiz edip değerlendirebilen ve aynı zamanda da kendi mesajlarını kendisi üretebilen bir birey olarak tanımlanabilir (Altun, 2009, 1). Burn ve Durran (2007) medya okuryazarlığını tanımlarken üç ana özelliği vurgulamışlardır. Bu özellikler; kültürellik, 
kritiklik ve yaratıcılıktır. Bu özellikleri sınıflarken bunların aynı zamanda medya okur-yazarlığının da özellikleri olduğunu belirtmişlerdir. Bu durumda bir medya aracını ya da araçlarını seçme durumu kültürel bir durum olabileceği gibi kritik yapmayı gerektiren bir durum da olabilir. Örnek olarak, televizyon seyretmek bir kültür olsa da hangi kanalı ya da kanalları izlemeyeceğini seçme kritik yapma becerisini gerektirmektedir. Bu özelliklerin kazanılması için bireyin iyi bir eğitim sürecinden geçmesi daha etkili bir medya okur-yazarı olması açısından önemli görülmektedir (Sarsar ve Engin, 2015, 168).

Türkoğlu $(2016,266)$ medya okuryazarlığının yalnızca beceri kazanmaya değil, "eleştirel ve demokratik yurttaşlık" çerçevesinde günümüz toplumlarının yeni bir açığına vurgu yaptığını söyleyerek, kavramın, yalnızca pratik işlevsel ve araçsal bir gereksinimi değil, eleştirel aklın gerekliğini gündeme getirdiğini vurgulamaktadır. Medya okuryazarlığına yurttaşlık bilinci açısından yaklaşan Binark ve Bek de (2010, 10-11) medya okuryazarlığının, yurttaşın toplumsal, kültürel, siyasal ve ekonomik alanlarda etkin aktör olarak her türlü karar mekanizmasında yer almasını, aldığı kararların da sorumluluğunu üstlenmesini, öz-düşünümsel bir bilinç ile sorumluluk etiği geliştirmesini desteklediğini ifade etmektedir. İnceoğlu $(2016,21)$ medya okuryazarlığını daha geniş boyutta ele alarak, MOY kavramının çeşitli amaçları kapsadığını ve bu amaçların; "demokrasi, yurttaşlık bilinci ve siyasal katılımı teşvik etme", "ırk, sınıf ve toplumsal cinsiyet ayrımcılığını asgariye indirme", "uyuşturucu kullanımı- şiddeti önleme", "eğitim düzeyini iyileştirme" ve benzerleri olduğunu vurgulamaktadır. Alver'e $(2006,23)$ göre ise medya okuryazarlığının amacı aslında, yalnızca medyanın olumsuz etkilerinin bilişsel olarak giderilmesi için beceri ve yeteneklerin kazandırılması değildir, giderek daha güçlü bir şekilde medya tarafından belirlenen yaşam alanlarının korunmasıdır.

Sonuçta medya okuryazarlık düzeyi düşük olan bireyler için görsel-işitsel paylaşımda yaşanan yoğunluk, istenmeyen durumlara sebep olabilir. Birey doğru okuma biçimleri geliştiremediyse bu paylaşımlar onun sömürülmesine ya da yanlış yönlendirilmesine neden olabilir (Gül, 2013). Medya ve televizyon aracılığıyla insanların bilinçsiz olarak ve önemli düzeyde yönlendirilmeye açık oldukları; insanların çoğu kez okudukları ya da izledikleri haberleri irdelemeksizin kabul ederek tepkiler geliştirdikleri (Korkmaz ve Yeşil, 2011, 113) bilinen bir gerçektir. Günümüz toplumunda, okul çağında ya da yetişkinler için, eleştirel düşünme yetkinliklerini kazanım olarak kabul edecek medya okuryazarlığı eğitimi, katılımcıların/öğrencilerin tarihsel süreçte kendi rollerini belirlemesi ve etkin özneler/yurttaşlar olmak için ilk adımı atmaları biçiminde düşünülmektedir (Dağtaş ve Okuroğlu, 2018, 396). Bu çerçevede bireye kazandırdığı eleştirel düşünme yeteneğinin öneminin fark edilmesi ve yaşam boyu öğrenme için gerekli olan donanıma sahip olmayı kolaylaştıran medya okuryazarlığının ve medya okuryazarlık eğitiminin, iletişim teknolojilerinin gelişimiyle birlikte dünyada ve Türkiye'de önemi gün geçtikçe artmaktadır.

\section{Dünyada ve Türkiye'de Medya Okuryazarlığı}

1920'li yıllardan itibaren medyanın programlı bir biçimde eğitimde ele alınmaya başlanması ve bir öğretim konusu olarak kabul edilmesiyle başlayan süreçte, bugün artık iletişim bilimcilerin yanı sıra ilk ve orta düzeyde görev alan eğitimciler de medya konusunda bilgilenme ve bilinçlenmenin çok erken dönemlerden itibaren başlaması gerektiği üzerinde durmaktadır. Nitekim pek çok ülkede, 
medya okuryazarlığı konusunda ulusal bir politika belirlendiği; ilk ve ortaöğretim müfredatlarında medya eğitimi, medya pedagojisi, medya okuryazarlığı gibi çeşitli derslere ve uygulamalara yer verildiği görülmektedir (Erdoğan, 2010,48).

Medya okuryazarlığı eğitimi, 20. yüzyılın başlarında, önce Amerika ve Kanada'da daha sonra da Avrupa'da farklı şekilde gelişmiştir (Hasdemir, 2012, 23). Medya okuryazarlığı kavramının yaygınlaşması ise 1982 yılında UNESCO'nun gerçekleştirmiş olduğu bir toplantının bildirisinde yer almasıyla başlamıştır. Bu toplantı sonrasında Avrupa Birliği üye devletleri arasında medya okuryazarlığıyla ilgili olarak çeşitli uygulamalar görülmesine rağmen, medya okuryazarlığı 2000 yılında Lizbon'da gerçekleşen zirve ile AB'nin gündemine girmiştir. Zirvede; yeni enformasyon ve iletişim teknolojisine dayalı bilgi toplumu ve bilgi ekonomisinin şekillendirildiği geleceğin Avrupasını ve yaşam boyu öğrenimin desteklenmesi, eğitime genel bütçede ayrılan payın artırılması, enformasyon teknolojilerini kullanma becerilerinin geliştirilmesi üzerinde durulmuştur (Binark ve Bek, 2010, 73). Pek çok ülkede Medya Eğitimi, Medya Okuryazarlığı, Medya Alfabesi gibi değişik adlarla uygulanmaya başlayan programlar gün geçtikçe yaygınlık kazanmıştır (Görmez, 2015, 95).

Ülkemizde medya okuryazarlığı 2000'li yıllarda gündeme gelmiş ve bu konudaki önemli gelişmelerden biri; 23-25 Mayıs 2005 tarihinde Marmara Üniversitesi İletişim Fakültesi tarafından gerçekleştirilen I. Uluslararası Medya Okuryazarlığı Konferansı olmuştur. Konferansın sonuç bildirgesinde medya okuryazarlığı ile ilgili ders açılması önerisinin ve medya okuryazarlığı konusunda akademik ilgi oluşturmasının medya okuryazarlığına önemli katkısı olmuştur (Altun, 2009, 11). Türkiye'de medya okuryazarlığı eğitimi ise, RTÜK ve MEB arasında 22 Ağustos 2006 tarihinde imzalanan işbirliği protokolü ile başlamıştır. Protokole göre; 2006-2007 öğretim yılında beş ilköğretim okulunda pilot olarak başlatılan Medya okuryazarlığı dersi, 2007-2008 öğretim yılından itibaren Türkiye'nin 81 il genelinde ilköğretim okullarında 6, 7 ya da 8. sınıfların birinde okutulmak üzere seçmeli ders olarak programa girmiştir (RTÜK, 2014).

Medya okuryazarlığının modern toplumun karşı karşıya kaldığı karmaşık sorunların anlaşılması için gerekli olan eleștirel düşünme becerilerini geliștirmesi noktasından, eleştirel medya okuryazarlığının eleştirel pedagojinin temel öğeleri ile benzerlikler taşıdığı ifade edilmektedir (Binark ve Bek, 2010, 110). Temel öğeler kapsamında ele alındığında; medya okuryazarlığı otorite, egemenlik, iletişim süreçleri, tahakküm, psikolojik etkiler gibi temel sorunlar üzerinde dururken eleştirel pedagoji de benzer sorunları pedagojik bağlamda ele almaktadır. Eleştirel pedagoji başta olmak üzere eğitim programlarına yönelik çalışmalar ve çokkültürlü eğitim anlayışı, önyargıların (stereotiplerin) ve yerleşik mitlerin ders materyallerinden ve öğretim ortamlarından temizlenmesiyle ilgilenirken; medya okuryazarlığı medya alanında bu sorunların hangi şekillerde ortaya çıktığını ve bilinçler üzerinde nasıl bir güdüm oluşturduğunu deşifre etmektedir (Şahin, 2014, 240). Bu bağlamda Medya Okuryazarlığı dersinin eleştirel bakış açısını geliștirme ve bireylerin medya iletilerini doğru okuma ve yorumla becerisi oluşturma amacı taşıması, eleştirel pedagojinin temel amaçlarıyla paralel bir düzlem teşkil etmektedir. 


\section{Amaç}

Bu araştırma ile İletişim Fakültesi öğrencilerinin medya okuryazarlığını ve Medya Okuryazarlığı dersini nasıl algıladığı ve ilköğretim eğitiminde alınan dersin, öğrenim çıktısı olarak medya hakkında bilinçlenme yaratıp yaratmadığının saptanması amaçlanmıştır.

\section{Yöntem}

\section{Araştırmanın Modeli}

$\mathrm{Bu}$ amaç doğrultusunda konunun özelliğine ve araştırmanın amacına uygun olan tarama modeli kullanılmıştır. Tarama modeli, geçmişte veya şu anda var olan bir durumu var olduğu şekliyle betimlemeyi amaçlayan araştırma modelidir (Merter, 2009 , 83). Araştırmaya konu olan olay, birey ya da nesne, kendi koşulları içinde ve olduğu gibi tanımlanmaya çalıșılır (Karasar, 2008). Tarama modelinin yanı sıra ilköğretim eğitiminde medya okuryazarlı̆̆ı dersi alanların, dersin öğrenim çıktısı olarak medya hakkında bilinçlenip bilinçlenmediğini ölçümleyebilmek için yarı yapılandırılmış görüşme tekniği kullanılmıștır. Yirminci yüzyılın son çeyreğinde pek çok sosyal bilim alanında etkili bir veri toplama yöntemi olarak kullanılan görüşme, deneyimler, tutumlar, düşünceler ve yorumlar gibi gözlenemeyenin anlaşılmasına katkıda bulunmaktadır (Şimşek ve Yıldırım, 2016).

\section{Evren ve Örneklem}

Bu çalışmanın evreni, İstanbul Aydın Üniversitesi İletişim Fakültesinde 2. Sınıf ders programında yer alan Medya Okuryazarlığı dersini almış 856 kişiden oluşmaktadır. Araştırmanın örneklemini ise İletişim Fakültesi 2., 3. ve 4. sınıf sınıflarında aktif olarak öğrenim gören ve tesadüfi örnekleme metoduyla seçilen 145'i (\%55) erkek, 120'si (\%45) kadın toplam 265 öğrenci olușturmaktadır. Örneklemin içinde yer alan Medya Okuryazarlığı dersini ilköğretimde görmüş olan 7 katılımcı ile de ayrıca yarı yapılandırılmış görüşme gerçekleştirilmiştir.

Tablo 1: Çalışma Grubunun Cinsiyet Dağılımı

\begin{tabular}{|l|c|c|}
\hline Cinsiyet & Öğrenci Sayısı & Yüzde (\%) \\
\hline Erkek & 145 & 55 \\
\hline Kadın & 120 & 45 \\
\hline Toplam & 265 & 100 \\
\hline
\end{tabular}

\section{Veri Toplama Araçları}

İstanbul Aydın Üniversitesi İletişim Fakültesi birinci sınıf haricindeki öğrencilerin medya okuryazarlığı dersini nasıl algıladığı ve ilköğretim eğitiminde alınan dersin, öğrenim çıktısı olarak medya hakkında bilinçlenme yaratıp yaratmadığının saptanması için iki bölümden oluşan bir anket formu hazırlanmış ve yarı yapılandırılmış görüşme tekniği uygulanmıștır.

Anket formunun ilk bölümünde katılımcıların sosyo-demografik özelliklerine ve mezun oldukları ilkokul bilgilerine yer verilirken ikinci bölümde Medya Okuryazarlığı dersinin algılanmasına ilişkin olarak 5'li likert tipinde ölçek kullanılmıştır. Yapılan güvenilirlik testi sonucunda Cronbach's Alpha değeri 0,907 çıkmıştır Ayrıca ilköğretimde Medya Okuryazarlığı dersi görmüş katılımcılara, yarı yapılandırılmış görüşme tekniği ile "açık-uçlu sorulardan oluşan bir anket" uygulanmış ve "içerik analizi tekniği” kullanılarak analiz edilmiștir. 


\section{Verilerin Analizi}

Araştırmanın amacı kapsamında öğrencilere uygulanan anketlerde yer alan ve öğrencilerin görüşlerini belirlemeye yönelik olarak "Kesinlikle Katılmıyorum", "Katılmıyorum", "Kararsızım", "Katılıyorum", "Kesinlikle Katılıyorum” seçenekleri önem derecesine göre 1, 2, 3,4, 5 biçiminde derecelendirilmiştir. Elde edilen veriler SPSS 24.0 (Statistical Package for Social Science) paket programında işlenerek analiz edilmiştir.

\section{Bulgular}

Çalışma kapsamında; Medya Okuryazarlığı dersinin öğrencilerin medyayı kullanım alışkanlıkları üzerinde farklılık oluşturup oluşturmadığına, medya endüstrilerinin siyasi görüşü ve sermaye yapılanmaları ile yayınladıkları haberler arasında bağlantı kurup kurmadığına, ilköğretimde bu dersi alanların medyaya yönelik bilinç geliştirip geliștirmediklerine ilișkin bulgulara yer verilmiștir.

Tablo 2: Çalışma Grubunun Mezun Olduğu İlköğretim Dağılımı

\begin{tabular}{|l|c|c|}
\hline Mezun Olduğu İlköğretim & Öğrenci Sayısı & Yüzde (\%) \\
\hline Devlet İlköğretim Okulu & 228 & 86 \\
\hline Özel İlköğretim Okulu & 32 & 12 \\
\hline Pansiyonlu İlköğretim Okulu & 2 & 1 \\
\hline Diğer & 3 & 1 \\
\hline Toplam & 265 & 100 \\
\hline
\end{tabular}

Tablo 2'de görüldüğ̈ üzere araştırmaya katılan 265 öğrencinin 228'i (\%86) devlet ilköğretim okulundan, 32'si (\%12) özel ilköğretim okulundan, 2'si (\%1) pansiyonlu ilköğretim okulundan, 3'ü (\%1) ise diğer başlığında yurtdışında bir ilköğretim okulundan mezun bulunmaktadır.

Tablo 3: "Medyayı Sik Sik Takip Ediyorum"

\begin{tabular}{|l|c|c|}
\hline & Öğrenci Sayısı & Yüzde (\%) \\
\hline Kesinlikle Katılmıyorum & 10 & 3,77 \\
\hline Katılmıyorum & 10 & 3,77 \\
\hline Kararsızım & 12 & 4,53 \\
\hline Katılıyorum & 97 & 36,60 \\
\hline Kesinlikle Katılıyorum & 136 & 51,32 \\
\hline
\end{tabular}

“Medyayı Sık Sık Takip Ediyorum" ifadesine öğrencilerden 136'sı (\%51,32) kesinlikle katılırken, 97'si $(\% 36,60)$ katılmakta, 12'si $(\% 4,53)$ ise kararsız kalmaktadır. Bu ifadeye katılmayan öğrenci sayısı ise toplamda $10^{\prime}$ dur $(\% 7,54)$. Verilerden elde edilen bulgulara göre; öğrencilerin yaklaşık \% 87 gibi yüksek oranı medyayı sık olarak takip etmektedir.

Tablo 4: "Medyanın Toplumun Ve Bireylerin İnanç, Tavır Ve Davranışları Üzerinde Çok Etkili Olduğunu Düşünüyorum"

\begin{tabular}{|l|c|c|}
\hline & Öğrenci Sayısı & Yüzde (\%) \\
\hline Kesinlikle Katımıyorum & 16 & 6,04 \\
\hline Katılmıyorum & 14 & 5,28 \\
\hline Kararsızım & 31 & 11,70 \\
\hline Katılıyorum & 92 & 34,72 \\
\hline Kesinlikle Katııyorum & 112 & 42,26 \\
\hline
\end{tabular}


"Medyanın Toplumun Ve Bireylerin İnanç, Tavır Ve Davranışları Üzerinde Çok Etkili Olduğunu Düşünüyorum" ifadesine öğrencilerin toplam 204'ü $(\% 76,98)$ katılırken, 31'i $(\% 11,70)$ ise kararsız kalmaktadır. Bu ifadeye kesinlikle katılmayan öğrenci sayısı toplamı $30(\% 11,32)$ dir. Bu durumda; öğrencilerin yaklaşık \% 77'si medyanın toplumun ve bireylerin inanç, tavır ve davranışları üzerinde çok etkili olduğunu düşünmektedir.

Tablo 5: "Medya Okuryazarlığı Dersi Öğrencilerin Medyaya Karşı Yaklaşımlarında Ve Medyayı Kullanım Alışkanlıkları Üzerinde Farklılık Yaratmaktadır"

\begin{tabular}{|l|c|c|}
\hline & Öğrenci Sayısı & Yüzde (\%) \\
\hline Kesinlikle Katılmıyorum & 12 & 4,53 \\
\hline Katılmıyorum & 16 & 6,04 \\
\hline Kararsızım & 50 & 18,87 \\
\hline Katılıyorum & 121 & 45,66 \\
\hline Kesinlikle Katılıorum & 66 & 24,91 \\
\hline
\end{tabular}

"Medya Okuryazarlığı Dersi Öğrencilerin Medyaya Karşı Yaklaşımlarında Ve Medyayı Kullanım Alışkanlıkları Üzerinde Farklılık Yaratmaktadır” ifadesine öğrencilerden 66'sı (\%24,91) kesinlikle katılırken, 121'i $(\% 45,66)$ katılmakta, 50'si $(\% 18,87)$ ise kararsız kalmaktadır. Bu ifadeye kesinlikle katılmayan öğrenci sayısı $12(\% 4,53)$, katılmayan öğrenci sayısı $16(\% 6,04)$ tür. Verilerden elde edilen bulgulara göre; öğrencilerin yaklaşık \% 70’i Medya Okuryazarlı̆̆ı Dersinin öğrencilerin medyaya yaklaşımlarında ve medyayı kullanım alışkanlıklarında farklılık yarattığını ifade etmektedir.

Tablo 6: "Medya Okuryazarlığı Dersi, Medyanın Dilini Çözerek, Medyayı Daha Bilinçli Ve Etkili Bir Biçimde Kullanmamı Sağladı"

\begin{tabular}{|l|c|c|}
\hline & Öğrenci Sayısı & Yüzde (\%) \\
\hline Kesinlikle Katılmıyorum & 11 & 4,15 \\
\hline Katılmıyorum & 12 & 4,53 \\
\hline Kararsızım & 45 & 16,98 \\
\hline Katılıyorum & 120 & 45,28 \\
\hline Kesinlikle Katılıyorum & 77 & 29,06 \\
\hline
\end{tabular}

"Medya Okuryazarlığı Dersi, Medyanın Dilini Çözerek, Medyayı Daha Bilinçli Ve Etkili Bir Biçimde Kullanmamı Sağladı" ifadesine öğrencilerden 77'si $(\% 29,06)$ kesinlikle katılırken, 120 'si $(\% 45,28)$ katılmakta, 45'i $(\% 16,98)$ ise kararsız kalmaktadır. Bu ifadeye kesinlikle katılmayan öğrenci sayısı toplamı $23(\% 8,68)$ tür. Verilerden elde edilen bulgulara göre; öğrencilerin yaklaşık \% 75’i Medya Okuryazarlığı Dersinin medyayı daha bilinçli ve etkili bir biçimde kullanmasını sağladığını belirtmiştir.

Tablo 7: "Medya Okuryazarlı̆̆ı Dersi, Medya Endüstrilerinin Siyasi Görüşü, Sermaye Yapılanmaları İle Yayınladıkları Haberleri Arasında Bağlantı Kurmamı Sağladı"

\begin{tabular}{|l|c|c|}
\hline & Öğrenci Sayısı & Yüzde (\%) \\
\hline Kesinlikle Katılmıyorum & 14 & 5,28 \\
\hline Katılmıyorum & 18 & 6,79 \\
\hline Kararsızım & 54 & 20,38 \\
\hline Katılıyorum & 125 & 47,17 \\
\hline Kesinlikle Katılıorum & 54 & 20,38 \\
\hline
\end{tabular}


"Medya Okuryazarlığı Dersi, Medya Endüstrilerinin Siyasi Görüşü, Sermaye Yapılanmaları İle Yayınladıkları Haberleri Arasında Bağlantı Kurmamı Sağladı" ifadesine öğrencilerden 54'ü $(\% 20,38)$ kesinlikle katılırken, 125'i $(\% 47,17)$ katılmakta, 54'ü $(\% 20,38)$ ise kararsız kalmaktadır. Bu ifadeye kesinlikle katılmayan öğrenci sayısı toplamı $32(\% 12,07)$ dir. Verilerden elde edilen bulgulara göre; öğrencilerin yaklaşık \% 68'i Medya Okuryazarlığı dersinin medya endüstrilerinin siyasi görüşü, sermaye yapılanmaları ile yayınladıkları haberleri arasında bağlantı kurmasını sağladığını ifade etmiştir.

Tablo 8: "Medya Okuryazarlığı Dersi Sonrası, Medyayı Çözümleme, Değerlendirme Ve Kendi Medya Iletilerimi Üretme Gibi Beceriler Geliștirdim"

\begin{tabular}{|l|c|c|}
\hline & Öğrenci Sayısı & Yüzde (\%) \\
\hline Kesinlikle Katımıyorum & 15 & 5,68 \\
\hline Katılmıyorum & 11 & 4,17 \\
\hline Kararsızım & 40 & 15,15 \\
\hline Katıııorum & 130 & 49,24 \\
\hline Kesinlikle Katılıyorum & 68 & 25,76 \\
\hline
\end{tabular}

"Medya Okuryazarlığı Dersi Sonrası, Medyayı Çözümleme, Değerlendirme Ve Kendi Medya İletilerimi Üretme Gibi Beceriler Geliştirdim" ifadesine öğrencilerin toplam 198'i (\%75) katılırken, 26’sı (\%9,85) katılmamaktadır. Katılımcıların 40’ı $(\% 15,15)$ ise kararsız kalmıștır.

Araștırmaya katılan öğrencilere ilköğretimde medya okuryazarlığı dersi alıp almadığı sorulduğunda; 265 öğrencinin 208'nin $(\% 78,79)$ dersi almadığını, devlet ilköğretim okulunda eğitimini tamamlayan 50'sinin $(\% 18,94)$ ise aldığı belirlenmiştir. $6(\% 2,27)$ öğrenci ise dersi alıp almadığını hatırlayamamıștır. Bu tespit üzerine dersin medya ilişkin bir bilinç oluşturup oluşturmadığına ilişkin sorulan soruya ise öğrencilerden sadece 36’sı $(\% 13,64)$ olumlu cevap vermiştir.

Tablo 9: "Medya Okuryazarlığı Dersinin Illköğretim Müfredatında Zorunlu Ders Kapsamina Alınması Gereklidir"

\begin{tabular}{|l|c|c|}
\hline & Öğrenci Sayısı & Yüzde (\%) \\
\hline Kesinlikle Katılmıyorum & 21 & 7,95 \\
\hline Katılmıyorum & 16 & 6,06 \\
\hline Kararsızım & 65 & 24,62 \\
\hline Katılıyorum & 87 & 32,95 \\
\hline Kesinlikle Katııyorum & 75 & 28,41 \\
\hline
\end{tabular}

"Medya okuryazarlığı dersinin ilköğretim müfredatında zorunlu ders kapsamına alınması gereklidir" ifadesine öğrencilerin toplam 162'si (\%61,36) katılırken, 37'si $(\% 14,01)$ katılmamaktadır. Katılımcıların 65'i $(\% 24,62)$ ise kararsız kalmıştır.

Tablo 10: "Medya Okuryazarlığının Sadece Eğitim Kurumlarında Öğrencilere Ders Olarak Değil, Tüm Vatandaşlara Yaşam Boyu Verilecek Bir Ders Olarak Görüyorum"

\begin{tabular}{|l|l|l|}
\hline & Öğrenci Sayısı & Yüzde (\%) \\
\hline Kesinlikle Katılmıyorum & 14 & 5,28 \\
\hline Katılmıyorum & 17 & 6,42 \\
\hline Kararsızım & 45 & 16,98 \\
\hline Katılıyorum & 91 & 34,34 \\
\hline Kesinlikle Katılıyorum & 98 & 36,98 \\
\hline
\end{tabular}


"Medya Okuryazarlığının Sadece Eğitim Kurumlarında Öğrencilere Ders Olarak Değil, Tüm Vatandaşlara Yaşam Boyu Verilecek Bir Ders Olarak Görüyorum" ifadesine öğrencilerin toplam 189'u $(\% 71,32)$ katılırken, 45'i $(\% 16,98)$ ise kararsız kalmaktadır. Bu ifadeye katılmayan öğrenci sayısı toplamı $31(\% 11,07)$ dir. $\mathrm{Bu}$ durumda; öğrencilerin yaklaşık \% 71'i medya okuryazarlığının değișen teknoloji ve iletişim kanalları aracılığıyla düzenli olarak topluma anlatılması gerektiğini düşünmektedir.

Tablo 11: "Medya Okuryazarlığı Hakkında Yetişkin Bireylere, Kitle İletişim Araçları İle Bilgilendirici Yayın Yapılması Gerektiğini Düşünüyorum"

\begin{tabular}{|l|c|c|}
\hline & Öğrenci Sayısı & Yüzde (\%) \\
\hline Kesinlikle Katılmıyorum & 12 & 4,55 \\
\hline Katılmıyorum & 14 & 5,30 \\
\hline Kararsızım & 43 & 16,29 \\
\hline Katılıyorum & 108 & 40,91 \\
\hline Kesinlikle Katılıyorum & 87 & 32,95 \\
\hline
\end{tabular}

"Medya Okuryazarlığı Hakkında Yetişkin Bireylere, Kitle İletişim Araçları İle Bilgilendirici Yayın Yapılması Gerektiğini Düşünüyorum" ifadesine öğrencilerin toplam 195'i $(\% 73,86)$ katılırken, 43'ü $(\% 16,29)$ ise kararsız kalmaktadır. Bu ifadeye katılmayan öğrenci sayısı toplamı $26(\% 9,85)$ dır. Bu sonuç Tablo 10'da çıkan bulguları desteklemekte ve yetişkinlere informel olarak medya okuryazarlığına yönelik yayın yapılması gerekliliği düşünülmektedir.

Tablo 12: "Medya Okuryazarlığı Dersinin Illköğretimde Pedagojik Formasyon Almış İletişim Fakültesi Mezunları Tarafından Verilmesi Gerektiğini Düşünüyorum"

\begin{tabular}{|l|c|c|}
\hline & Öğrenci Sayısı & Yüzde (\%) \\
\hline Kesinlikle Katılmıyorum & 16 & 6,06 \\
\hline Katılmıyorum & 13 & 4,92 \\
\hline Kararsızım & 45 & 17,05 \\
\hline Katılıyorum & 89 & 33,71 \\
\hline Kesinlikle Katılıyorum & 101 & 38,26 \\
\hline
\end{tabular}

"Medya Okuryazarlığı Dersinin İlköğretimde Pedagojik Formasyon Almış İletişim Fakültesi Mezunları Tarafından Verilmesi Gerektiğini Düşünüyorum” ifadesine öğrencilerin toplam 190'ı (\%71,97) katılırken, 45'i $(\% 17,05)$ ise kararsız kalmaktadır. $\mathrm{Bu}$ ifadeye katılmayan öğrenci sayısı toplamı $29(\% 10,98)$ dir. Bu durumda; öğrencilerin yaklaşık \% 72'si ilköğretim eğitiminde verilen Medya Okuryazarlığı Dersinin iletişim fakültesi mezunlarınca verilmesi gerektiğini düşünmektedir.

İlköğretimde Medya Okuryazarlığı dersi alan ve tamamı devlet ilköğretim okullarında eğitimlerini tamamlamış olan 50 öğrencinin 7'si ile yapılan yarı yapılandırılmış görüşmede şu bulgulara ulaşılmıştır:

Yarı yapılandırılmış görüşmeye alınan katılımcıların 3'ü altıncı sınıfta, 4'ü yedinci ve sekizinci sınıfta Medya Okuryazarlığı dersini seçmeli olarak almıştır. Medya Okuryazarlığı adıyla verilen dersin hangi branş öğretmeni tarafından verildiği sorusuna; 2 katılımcı Matematik öğretmeni, 3 katılımcı Türkçe öğretmeni, 1 katılımcı Sosyal Bilgiler öğretmeni, 1 katılımcı Tarih öğretmeni tarafından verildiğini belirtmiştir. Ders içeriğinde işlenen konulardan neler hatırladığı sorusuna; 6 katılımcının verdiği görüşler şu şekildedir: 
- $(\mathrm{K}=1)$ "Gazetelerden haber toplama, kesme, deftere yapıştırma yapıldı."

- (K=2) "Gündem takip edildi ve haberler tartışıldı."

- $(\mathrm{K}=3)$ "Televizyon hakkında görüşüldü ve kitap okundu."

- $(\mathrm{K}=4)$ "Derste gazete inceleniyor ve haberler okunuyordu."

- (K=5) "Nasıl iletişim kurmalı konuşuldu, medyanın kurgusallığı, medyadaki belirli olaylar, haberler inceleniyor, kişisel düşünceler katarak yorumlama yapılıyordu."

- $(\mathrm{K}=6)$ "Medya içeriklerine eleștirel bakma ve medyanın kurgusallı̆̆ı üzerine konuşuluyordu"

1 katılımcı $(\mathrm{K}=7)$ ise "Ders içeriğine ilişkin bir konu görmedim. Sadece sınavdan önce dağıtılan notlar ile sınava hazırlandım. Dersler daha çok matematik dersine takviye olarak geçti" şeklinde dersin işleniş yönteminin ders öğrenim çıktılarıyla örtüşmediğini gösteren bir görüş bildirmiştir.

Diğer katılımcılar her ne kadar medya iletilerinin haberler özelinde incelendiğine ilişkin görüş bildirseler de, uygulamaya yönelik olarak kendi medya iletilerini oluşturmaları konusunda hiç bir veriye ulaşılmamıştır.

Hasdemir'in $(2012,27)$ yaptığı çalışmada da, Medya Okuryazarlığı dersinde belli başlı medya araçlarını ve kullanma biçimlerini didaktik biçimde anlatarak öğrenciye eleştirel bir bakış açısı ve farkındalık kazandırmanın olanaklı olmadığı sonucuna ulaşılmıştır. Öğrencinin bir medya aracı ve uygulamalarıyla ilgili yapım-oluşturma aşamasından sunumuna kadar birbirini izleyen süreçleri, süreçleri biçimlendiren dinamiklerle birlikte kavraması önemlidir. Bunun yanı sıra ve kavrayıșı da kuvvetlendirmek bakımından öğrencinin bizzat konuyla ilgili kendi medya ürününü yaratması çok önemlidir.

Ancak RTÜK'ün 2012 yılında ilköğretim 7. ve 8. sınıf öğrencilerine yönelik yaptığı araştırmaya katılan ve Medya Okuryazarlığı dersini alan \% 53 oranındaki öğrenci, kendilerine yöneltilen "Medya Okuryazarlı̆̆ı dersini genel olarak nasıl değerlendiriyorsunuz?" sorusuna, \% 91 oranında az ya da çok yararlı buldukları şeklinde cevap vermiştir. Dersi çok yararlı bulduğunu belirten öğrencilerin oranı \% 30'dur.

\section{Sonuç}

Medyanın toplum üzerindeki büyük etkisini görmemek mümkün değildir. Özellikle kitle iletişim araçları aracılığıyla medya ekonomik, toplumsal, siyasal, kültürel alanda küçümsenemeyecek etkiler yaratmakta toplumsal değişim sürecinin baş aktörü olarak görülmektedir (Elma ve diğerleri, 2010). Kitle iletişim araçları ve yeni medyanın gelişimiyle birlikte iletişimin ticarileşerek ulusal ve uluslararası şirketlerin kontrolüne girmesi, özellikle sosyal medyada ulaşılan bilginin doğrulanma sorunu, medya iletilerine eleştirel bir bakış açısıyla yaklaşılmasını zorunlu hale getirmektedir. Bu bağlamda, medya iletilerinin analiz edilme gereksinimi ile bireyleri bilinçlendiren, bilgiyi yorumlayabilen ve sorgulayabilen, çok yönlü düşünebilen bir bakış açısına kavuşturabilmek açısından, medya okuryazarlığı ve eğitimi büyük önem taşımaktadır.

Bu çalışmadaki araştırma bulgularında; medyayı sık olarak takip eden öğrencilerin yaklaşık \% 77'sinin medyanın, toplumun ve bireylerin inanç, tavır ve davranışları üzerinde çok etkili olduğunu düşündüğü ortaya çıkmaktadır. Katılımcıların yaklaşık \%75'i, Medya Okuryazarlığı dersinin medyaya yaklaşımlarında ve medyayı kullanım 
alışkanlıklarında farklılık yarattığını, dersin medyayı daha bilinçli ve etkili bir biçimde kullanmasını sağladığını ifade etmiştir. Yine büyük bir kesimi de dersin, medya endüstrilerinin siyasi görüşü, sermaye yapılanmaları ile yayınladıkları haberleri arasında bağlantı kurmasına yardımcı olduğunu düşündüklerini ve Medya Okuryazarlığı dersi sonrası, medyayı çözümleme, değerlendirme ve kendi medya iletilerini üretme gibi beceriler geliştirdiklerini ifade etmişlerdir. Medya Okuryazarlığı dersinin medyayı sorgulamayı ve medya içeriklerine karşı çok yönlü ve eleştirel bir bakış açısı kazanmayı sağladığına ilişkin benzer bulgulara İlhan ve Aydoğdu (2015) ve Kansızoğlu'nun (2016) yaptığı çalışmalarda da ulaşılmıştır.

Araştırmaya katılan 265 öğrenciden sadece 50’si (\%18,94) ilköğretimde Medya Okuryazarlığı dersi aldığını beyan etmiș ve bu öğrencilerin 36'sı $(\% 13,64)$ dersin medyaya yönelik bilinç geliştirmesinde yararlı olduğunu söylemiştir. İlköğretimde Medya Okuryazarlığı dersi alan 50 öğrencinin hepsi devlet ilköğretim okulundan mezun olmuşlardır. Bu öğrenciler arasından 7 katılımcı ile yapılan yarı yapılandırılmış görüşmede ise dersin Matematik, Türkçe ve Tarih öğretmenleri tarafından verildiği ifade edilmekte ve sadece bir katılımcının Sosyal Bilgiler öğretmeninden Medya Okuryazarlığı dersini aldığı görülmektedir. İlhan ve diğerlerinin $(2014,55)$ Ankara'nın Mamak, Keçiören, Çankaya, Altındağ ve Yenimahalle bulunan 5 İlköğretim okulunda öğrenim gören öğrencilere yaptığı araştırmada da, bu okullarda medya okuryazarlığı dersini veren öğretmenlerin hiçbirinin iletişim fakültesi mezunu olmadığı ve ders ile ilgili herhangi bir eğitim almadığı görülmüştür. $\mathrm{Bu}$, dersin daha yeterli bir şekilde verilebilmesi açısından olumsuz bir durumdur. Ağırlıklı olarak sosyal bilgiler branşı öğretmenleri tarafından okutulan dersi, Türkçe ve sınıf öğretmenlerinin yanı sıra diğer branşlardan öğretmenler de vermektedir. Hobbs'a göre medya metinlerinin analizi ve medya mesajlarının üretilmesi süreci, dersin önemli bir bölümünü teşkil eder ve bu tarz bir çalışmanın nasıl uygulanması gerektiğini bilmeyen bir öğretmen tarafından gerçekleştirilirse medya analiz ve üretim aktivitelerinin yüzeyselleştirilmesi tehlikesini taşır (Algan, 2016, 73).

Katılımcıların büyük çoğunluğu Medya Okuryazarlı̆̆ı dersinin ilköğretimde pedagojik formasyon almış iletişim fakültesi mezunları tarafından verilmesi gerektiği düşüncesindedir. Bu veri Solmaz ve Yılmaz'ın $(2012,61)$ yaptığı çalışmanın sonucu ile de örtüşmektedir. Bu bilgiler doğrultusunda medya okuryazarlığının amacına uygun bir eğitim verilebilmesi için, ilköğretimde seçmeli olarak müfredatta yer alan Medya okuryazarlığı dersinin, bu alanda eğitim almış iletişim fakültesi mezunları tarafından veya kuramsal ve uygulamalı hizmetiçi eğitim programları aracılığıyla yetiştirilen, konuyla alakalı olarak bilgi ve beceri düzeyleri gelişmiş ilgili branş öğretmenleri tarafından verilmesi gerektiği düşünülmektedir.

Barut ve diğerlerinin (2016) yaptı̆̆ı çalışmada da öğretmen eğitimi sürecinde Medya Okuryazarlığı dersinin eklenmesinin bir gereklilik olduğu ortaya çıkmıştır. Medya okuryazarlığı eğitiminin yaşam boyu tüm vatandaşlara verilmesi gereken bir eğitim olduğu (Li ve Li, 2010, 238) dünya çapında genel kabul görmüştür. Kellner ve Share (2007) de eğitimin eleştirel bir yaklaşımla yeniden yapılandırılması ve öğrenci, öğretmen ve vatandaşlar olarak medya okuryazarlığı ile medya kültürünün doğasını ve etkilerini ayırt edebilecek düzeyde eğitim yöntemlerinin geliştirilmesi gerektiğini belirtmişlerdir. 
Araştırmaya katılan iletişim fakültesi öğrencilerinin büyük çoğunlu da bu yaklaşımı onaylamakta ve Medya Okuryazarlığı dersinin medya iletilerinin kurgusallığına ve medyanın endüstriyel işleyişine yönelik olarak farkındalık geliştirilmesini sağladığını belirtmektedir. Temel olarak bakıldığında öğrencilerde Medya okuryazarlığı dersine yönelik olarak, medyayı kullanım alışkanlıklarında farklılık yaratma, medya içeriklerine karşı çok yönlü ve eleştirel bir bakış açısı kazandırma ile medyayı doğru yorumlamaya yardımcı olma algısı bulunmaktadır. Keza, ilköğretimde alınan medya okuryazarlığına ilişkin dersin de medya iletilerinin oluşturulmasında uygulamaya yönelik bir takım eksiklikleri olmasına rağmen öğrencilerin genel olarak medyayı doğru algılamasına ilişkin bilinç kazandırdığı da görülmektedir. Ancak bu dersin önemi doğrultusunda devlet ve özel ilköğretim okullarında daha yaygınlaştırılarak uygulamalı bir ders olarak müfredatta yer alması önerilebilir.

\section{Kaynakça}

Algan, E. (2016). Medya Okuryazarlığı Alanında Teorik Ve Pratik Yaklaşımlar. N. Türkoğlu ve M. C. Şimşek (Ed.). Medya Okuryazarlığı. İstanbul: Pales Yayınları.

Altun, A. (2009). 21. Yüzyıl Vatandaşlığı İçin Gerekli Bir Beceri Olarak Medya Okuryazarlığı: UNESCO, AB Ve Türkiye Örnekleri. I. Uluslararası Avrupa Birliği, demokrasi, Vatandaşlık ve Vatandaşlık Eğitimi Sempozyumu. Erişim: 5 Mayıs 2018, http://acikarsiv.gazi.edu.tr/index. php?menu=2\&secim=10\&YayinBIK=2275\#

Alver, F. (2006). Medya Yetkinliğinin Kuramsal Temelleri, KÍLAD Dergi, 7, 9-26.

Aslan, N. ve Basel, A. T. (2017). Eğitim Fakültesi Öğrencilerinin Medya Okur-Yazarlık Düzeyleri (İzmir Örneklemi). Kastamonu Eğitim Dergisi, 25(4), 1353-1372.

Aybek, B. ve Demir, R. (2014). Lise Öğrencilerinin Medya ve Televizyon Okuryazarlık Düzeylerinin Çeşitli Değişkenler Açısından İncelenmesi. Çukurova Üniversitesi Eğitim Fakültesi Dergisi, 43(1), 46-62.

Barut, E., Demirer, V., Erbaş, Ç., Dikmen, C. H. ve Sak, N. (2016). Öğretmen Adayları İçin Medya Okuryazarlığı Eğitimi: Öğretim Tasarımı Süreci Ve Değerlendirilmesi. Çukurova Üniversitesi Eğitim Fakültesi Dergisi, 45(1), 49-70.

Binark, M. ve Bek, M. G. (2010). Eleştirel Medya Okuryazarlığı Kuramsal Yaklasimlar ve Uygulamalar. (2. bs.). İstanbul: Kalkedon Yayınları.

Burn, A., ve Durran, J. (2007). Media Literacy in Schools: Practice, Production And Progression. Thousand Oaks, CA: SAGE Publications.

Dağtaş, E., ve Okuroğlu, M. S. (2018). Tarihsel Bir Kategori Olarak Burjuva Medya Okuryazarlığı. e-GIFDER, 6(1), 381-397.

Elma, C., Kesten, A., Dicle, A. N., ve Uzun, E. M. (2010). Türkiye'de Medya Okuryazarlığı Eğitimi: Medyanın İşleyişi Ve Etik İlkeler Açısından Bir Değerlendirme. Kuram ve Uygulamada Eğitim Bilimleri, 10(3), 1409-1458.

Erdoğan, M. T. (2010). Toplumsal Cinsiyet Eşitliğinin Sağlanmasında Medya Okuryazarlığının Rolü: Uzmanlık Tezi. TC Başbakanlık Kadının Statüsü Genel Müdürlüğ̈u.

Gedik, M. (2015). Türkçe Öğretmeni Adaylarının Medya Okuryazarlığına İlișkin Görüşleri. Atatürk Üniversitesi Türkiyat Araştırmaları Enstitüsü Dergisi, (54). 
Gomez L.,M. ve Gomez, K. (2007). Reading For Learning: Literacy Supports For 21stCentury. Work. Phı Delta Kappan. 89/ 3, 224-228. Erişim: 15 Nisan 2018, https://doi.org/10.1177/003172170708900313

Görmez, E. (2015). Etkili Medya Okuryazarlığı Eğitimi Ve Uygulamalarından Örnekler. Bitlis Eren Üniversitesi Sosyal Bilimler Enstitüsü Dergisi, 4(1).

Gül, A. A. (2013). Avrupa Birliği'nde Medya Okuryazarlığı: Düzenleme Ve Çalışmalarda Gözlemlenen Eğilimler. AJIT-e: Online Academic Journal of Information Technology . 4 (11), 15-33.

Hasdemir, T. A. (2012). Gelenekselden Yeni Medya Okuryazarlığına: Türkiye Örneğinde Bir Değerlendirme, Hitit Üniversitesi Sosyal Bilimler Enstitüsü Dergisi, 5( 2), 23-40.

Hobbs, R. (2004). Medya Okuryazarlığında Yedi Büyük Tartışma, M. T. Bağlı (Çev.), Ankara Üniversitesi Eğitim Bilimleri Fakültesi Dergisi, 37 (1), 122-140.

İlhan, E., Aydoğdu, E. ve Aydoğdu, A. G. (2014). Medya Okuryazarlığı Dersi ve Televizyon Algısına Etkisi (Ankara Örneği). Akdeniz Iletisim, (21).

İlhan, E. ve Aydoğdu, E. (2015). Medya Okuryazarlığı Dersi Ve Yeni Medya Algısına Etkisi. Erciyes İletişim Dergisi, 4(1), 52-68.

İnceoğlu, Y. (2016). Medyayı Doğru Okumak. N. Türkoğlu ve M. C. Şimşek (Ed.). Medya Okuryazarlığı (s.19-24). İstanbul: Pales Yayınları.

Jolls, T. ve Thoman E. (2008). 21. Yüzyıl Okuryazarlığı (Medya Okuryazarlığına Genel Bir Bakış ve Sınıf İçi Etkinlikler) C. Elma (Çev.). Ankara: Ekinoks Yayınevi.

Kansızoğlu, H.B. (2016). Türkçe Öğretmeni Adaylarının Medya Okuryazarlığı Dersine Yönelik Görüşleri. İlköğretim Online, 15(2), 469-486, Erișim: 20 Mayıs 2018, http://dx.doi.org/10.17051/io.2016.43360.

Karasar, N. (2008). Bilimsel Araştırma Yöntemi: Kavramlar-İlkeler-Teknikler. Ankara: Nobel Yayın Dağıtım.

Kellner, D. ve Share, J. (2007). Critical Media Literacy, Democracy, And The Reconstruction Of Education. In D. Macedo \& S.R. Steinberg (Eds.). Media Literacy: A Reader, 3-23. New York: Peter Lang Publishing.

Korkmaz, Ö. ve Yeşil, R. (2011). Medya Ve Televizyon Okuryazarlık Düzeyleri Ölçeği Geçerlilik Ve Güvenirlik Çalışması. Uluslararası İnsan Bilimleri Dergisi, 8(2), 110-126.

Kurt, A. A. ve Kürüm, D. (2010). Medya Okuryazarlığı Ve Eleştirel Düşünme Arasındaki İlișki: Kavramsal Bir Bakış. Mehmet Akif Ersoy Üniversitesi Sosyal Bilimler Enstitüsü Dergisi, (2), 20-34.

Li, Z., ve Li, L. (2010). Media Literacy Education Should Be Life-Long Education. In 2010 International Conference on Optics, Photonics and Energy Engineering (OPEE).

Manzo, K., K. (2007). Alliance Provides 'Core Principles' For Media Literacy. Education Week, 26, 42. 
Merter, F. (2009). Cumhuriyet-Dicle-İnönü Üniversitesi Eğitim Fakültesi İlköğretim Bölümü Öğrencilerinin Öğrenme Stilleri Ve Öğrenme Stillerini Farklılaştıran Sosyo-Ekonomik Faktörler. Dicle Üniversitesi Ziya Gökalp Eğitim Fakültesi Dergisi, 13, 78-96.

Mora, N. (2008). Medya Ve Kültürel Kimlik. Uluslararası Insan Bilimleri Dergisi, 5, ( 1), 1-14.

RTÜK. (2012). Medya Okuryazarlığı Dersi Araştırması, Ankara.

RTÜK. (2014). Radyo ve Televizyon Yayıncılığı Sektör Raporu, Ankara.

RTÜK. (2016). Medya Okuryazarlı̆̆ı Araştırması, Ankara.

Sarsar, F. ve Engin, G. (2015). Sınıf Öğretmeni Adaylarının Medya Okur-Yazarlık Düzeylerinin İncelenmesi. Ege Eğitim Dergisi, (16) 1, 165-176.

Schopenhauer, A. (2016). Okumak, Yazmak ve Yaşamak Üzerine, İstanbul: Say Yayınları.

Solmaz, B. ve Yılmaz, R. A. (2012). Medya Okuryazarlığı Araştırması Ve Selçuk Üniversitesi'nde Bir Uygulama. Selçuk Üniversitesi İletişim Fakültesi Akademik Dergisi, 7(3), 55-61.

Som, S., ve Kurt, A. A. (2012). Bilgisayar Ve Öğretim Teknolojileri Eğitimi Bölümü Öğrencilerinin Medya Okuryazarlık Düzeyleri. Anadolu Journal of Educational Sciences International, 2(1), 104-119.

Şahin, A. (2014). Eleştirel Medya Okuryazarlığı. (2. bs.). Ankara: Anı Yayıncılık.

Şimşek, H. ve Yıldırım, A.(2016). Sosyal Bilimlerde Nitel Araştırma Yöntemleri. (10. bs.). Ankara: Seçkin Yayıncılık.

Türkoğlu, N. (2016). Okuryazarlıktan Medya Okuryazarlığına: Şifrelerin Ortaklığını Aramak. N. Türkoğlu ve M. C. Şimşek (Ed.). Medya Okuryazarlığı (s.265-271). İstanbul: Pales Yayınları. 
